\title{
molecules
}

ISSN 1420-3049

http://www.mdpi.org

\section{Structure-Stability Relationships of Phthalocyanine Copper Complexes}

\author{
T. N. Sokolova ${ }^{1}$, T. N. Lomova ${ }^{1}$, M. E. Klueva ${ }^{1}$, E. E. Suslova ${ }^{1}$, V. E. Mayzlish ${ }^{2}$ and \\ G. P. Shaposhnikov ${ }^{2}$ \\ ${ }^{1}$ Institute of Non-aqueous Solution Chemistry of Russian Academy of Sciences, 153045, \\ Academicheskaya, 1, Ivanovo, Russian Federation \\ ${ }^{2}$ Ivanovo State Academy of Chemistry and Technology, 153000 Engels str., 7, Ivanovo, Russian \\ Federation \\ Tel.: +7 0932 378512, Fax: +7 0932 378509, E-mail: tnl@ihnr.polytech.ivanovo.su
}

Received: 14 March 2000 / Accepted: 11 April 2000 / Published: 12 June 2000

\begin{abstract}
The influence of $\mathrm{NO}_{2}, \mathrm{Br}$, and $\mathrm{COOH}$ function substituents in various positions of $\mathrm{Cu}(\mathrm{II}) \mathrm{Pc}$ on the reactivity of the latter concerning the dissociation of the metal - nitrogen bonds in proton donor solvents is discussed.
\end{abstract}

Keywords: Phthalocyanine complexes, dissociation, stability.

\section{Introduction}

The correlation between structure and reactivity of metallophthalocyanines has not been investigated systematically until now. Nevertheless, it is well known [1] that electro-optical, thermodynamic and acid-base properties, as well as reactivity are expressed as functions of the electronic effects arising from metal coordination with phthalocyanines or structural changes in the phthalocyanine macrocycle. Numerous metallophthalocyanine functional derivatives with substituents in the benzene rings have been synthesized and isolated in individual form, and their structure and spectral properties were investigated [2-6].

(C) 2000 by MDPI (http://www.mdpi.org). Reproduction is permitted for noncommercial purposes. 


\section{Results and Discussion}

For the present work a series of similar compounds was chosen to study the electronic and steric effects of substituents in the aromatic macrocycles. They are $\mathrm{CuPc}(\mathrm{R})_{\mathrm{m}}($ Formula $\mathbf{I})$, where $\mathrm{R}=3-\mathrm{NO}_{2}$; 4- $\mathrm{NO}_{2}$; 3-COOH; 4-COOH; (4-Br, 5- $\left.\mathrm{NO}_{2}\right) ; 3,5-\mathrm{COOH} ; 4,5-\mathrm{COOH}$, and $\mathrm{m}=4$ or 8 and copper(II)octaethylporphyrin CuOEP (Formula II). The coordination group $\mathrm{CuN}_{4}$ was chosen as the reaction center. The kinetics of dissociation of copper(II)phthalocyanines in hot concentrated sulfuric acid into the solvated metal cation and protonated macrocycle (destroyed under the experimental conditions) was studied (Equations 1, 2).

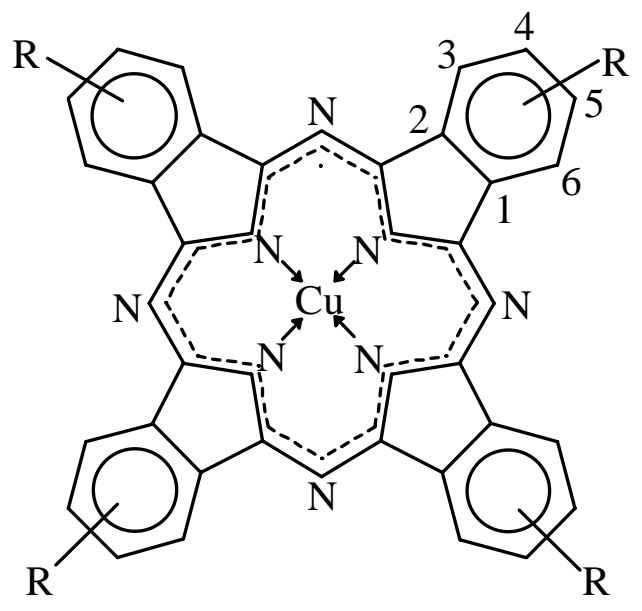

Formula I

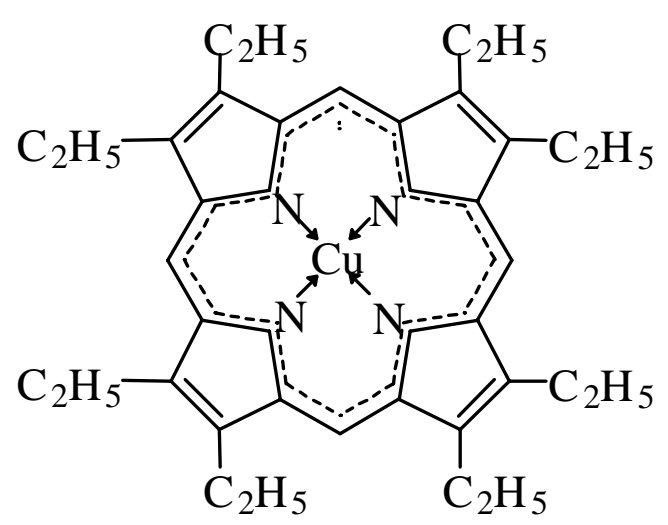

Formula II

$$
\begin{aligned}
& {\left[\mathrm{CuPc}(\mathrm{R})_{\mathrm{m}}\right]_{\text {Solv }}+2 \mathrm{H}_{\text {Solv }}^{+} \stackrel{k \text { dis }}{\longrightarrow}\left[\mathrm{H}_{2} \mathrm{Pc}(\mathrm{R})_{\mathrm{m}}\right]_{\text {Solv }}+\mathrm{Cu}_{\text {Solv }}^{2+}} \\
& {\left[\mathrm{H}_{2} \mathrm{Pc}(\mathrm{R})_{\mathrm{m}}\right]_{\text {Solv }} \stackrel{k_{\text {destr }}}{\longrightarrow} \text { the benzene derivatives }} \\
& k_{\text {dis }}<<k_{\text {destr }}
\end{aligned}
$$

The kinetics of Reaction 1 were studied spectrophotometrically. The decrease of concentration of the copper(II)phthalocyanines was measured as the decrease of optical density at certain wavelengths during heating their sulphuric acid solutions at a defined temperature (Fig.1).

To determine the form(s) of the phthalocyanines present in sulphuric acid, the dependence of their UV-vis spectra on the solvent nature was investigated (Table 1). The first absorption band $\mathrm{Q}(0,0)$ in the studied copper(II)phthalocyanines spectra practically retains its shape and the maximum position in the sulphuric acid of different concentrations within the Brand region. Only for $\mathrm{CuPc}\left(4-\mathrm{NO}_{2}\right)_{4}$ and $\mathrm{CuPc}(3-$ $\left.\mathrm{NO}_{2}\right)_{4}$ this band shifts hypsochromically and becomes single when the $\mathrm{H}_{2} \mathrm{SO}_{4}$ concentration is decreased up to $12 \mathrm{~mole} / \mathrm{L}$. It means that the copper(II)phthalocyanines in the concentrated sulphuric acid are in the same form for all investigated substituents $\mathrm{R}$ and for all acid concentrations in the Brand region 
where their reactivity was studied. A substantial hypsochromic shift of the $Q(0,0)$ band is observed in aprotic solvents compared with sulphuric acid solutions (Table 1). This testifies to protonation of the substituted compounds at outer-cycle $\mathrm{N}$ atoms and to a cation form $\mathrm{CuPc}(\mathrm{R})_{\mathrm{m}} \mathrm{H}^{+}$in the sulphuric acid solutions, analogous with non-substituted $\mathrm{CuPc}$ [1]. Thus in Equation (1) $\left[\mathrm{CuPc}(\mathrm{R})_{\mathrm{m}}\right]_{\text {solv }}=$ $\mathrm{CuPc}(\mathrm{R})_{\mathrm{m}} \mathrm{H}^{+}$. The rate law (Equation 3 ) and the rate constants formally obeyed the first order (Tables 2, 3) and describe Reaction 1 satisfactorily for all the investigated compounds.

$$
{ }^{-d C_{C u P c}(R)_{m} H^{+}} / d \tau=k_{o b s} \cdot C_{C u P c}(R)_{m} H^{+}
$$

Constants $k_{o b s}$ decrease with an increase of the initial acid concentration $\mathrm{C}_{\mathrm{H}_{2} \mathrm{SO}_{4}}^{0}$ non-linearly, in a smooth descending curve for all studied phthalocyanine complexes (except $\left.\mathrm{CuPc}(4-\mathrm{Br})_{4}\left(5-\mathrm{NO}_{2}\right)_{4}\right)$. Also, there is no linear correlation between $k_{o b s}$ and $\mathrm{H}_{0}$ values. We tried to correlate the rate constant values with the equilibrium concentrations of proton-donor particles in $\mathrm{H}_{2} \mathrm{SO}_{4}$.

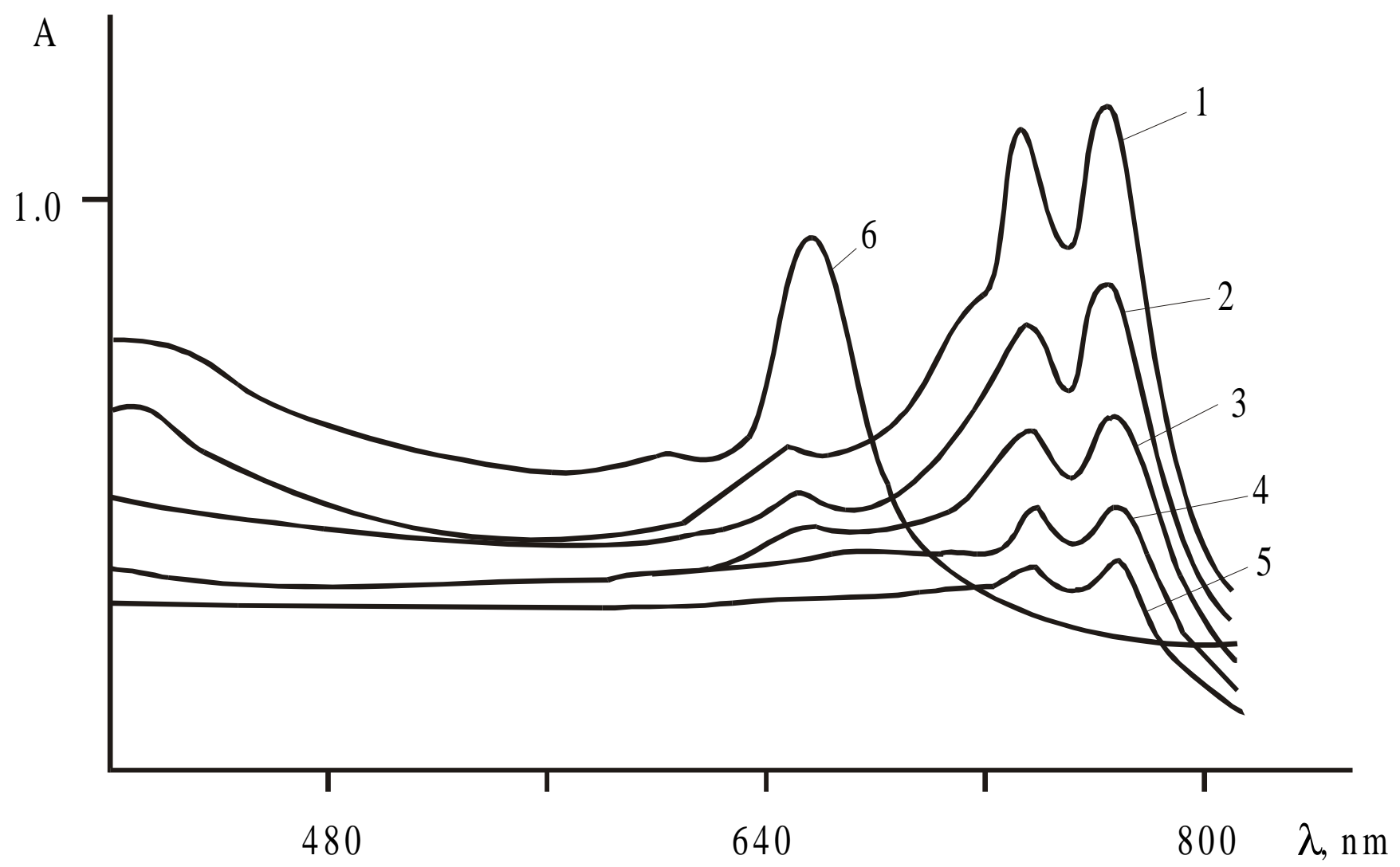

Figure 1. The electron absorption spectra of $\mathrm{CuPc}\left(4-\mathrm{NO}_{2}\right)_{4}$ in 16.67 mole/ $\mathrm{H}_{2} \mathrm{SO}_{4}, \mathrm{~T}=423 \mathrm{~K}(1-5), \tau$, s: 1 -1020, 2 - 1260, 3 - 1320, 4 - 1380, 5 - $\infty$ and in pyridine, $\mathrm{T}=298 \mathrm{~K}$ (6). 
Table 1. Position of the low energy maximum of the $\mathrm{Q}(0,0)$ band in the UV-vis spectra of copper(II)phthalocyanines $\left(\lambda_{\max }, \mathrm{nm}\right)$.

\begin{tabular}{|c|c|c|c|c|c|c|c|c|}
\hline Compound & \multirow{2}{*}{ DMFA } & \multirow{2}{*}{ Pyridine } & \multicolumn{5}{|c|}{ Sulphuric acid concentration $\mathrm{C}_{\mathrm{H}_{2} \mathrm{SO}_{4}}^{\circ}$, mole/L } \\
\cline { 4 - 9 } & & & 12.02 & 14.04 & 15.85 & 16.60 & 17.00 & 17.68 \\
\hline $\mathrm{CuPc}\left(3-\mathrm{NO}_{2}\right)_{4}$ & 669 & 669 & 700 & 713 & 719 & 732 & 729 & 733 \\
$\mathrm{CuPc}\left(4-\mathrm{NO}_{2}\right)_{4}$ & 669 & - & 727 & 761 & 758 & 753 & 766 & 761 \\
$\mathrm{CuPc}(4-\mathrm{Br})_{4}\left(5-\mathrm{NO}_{2}\right)_{4}$ & 666 & 686 & 741 & 745 & 741 & 740 & 745 & 740 \\
$\mathrm{CuPc}(3-\mathrm{COOH})_{4}$ & 665 & 687 & - & - & 718 & 725 & 725 & 723 \\
$\mathrm{CuPc}(4-\mathrm{COOH})_{4}$ & - & 685 & - & - & 776 & 776 & 777 & 776 \\
$\mathrm{CuPc}(3,5-\mathrm{COOH})_{8}$ & - & - & - & - & 725 & 731 & 730 & 726 \\
$\mathrm{CuPc}(4,5-\mathrm{COOH})_{8}$ & - & - & - & - & 745 & 750 & 750 & 750 \\
\hline
\end{tabular}

Table 2. Kinetic parameters of dissociation reactions of nitro derivatives of copper(II)phthalocyanine in sulphuric acid.

\begin{tabular}{|c|c|c|c|c|}
\hline \multirow{2}{*}{$\mathrm{C}_{\mathrm{H}_{2} \mathrm{SO}_{4}}{ }^{\prime}$} & \multicolumn{4}{|c|}{$\mathrm{k}_{\text {obs. }} \cdot 10^{4}, \mathrm{~s}^{-1}$} \\
\cline { 2 - 5 } mole/L & $379 \mathrm{~K}$ & $410 \mathrm{~K}$ & $423 \mathrm{~K}$ & $298 \mathrm{~K}$ \\
\cline { 2 - 5 } 15.85 & $8 \pm 3$ & $\mathrm{CuPc}\left(3-\mathrm{NO}_{2}\right)_{4}$ & \\
16.67 & $1.9 \pm 0.2$ & $19 \pm 2$ & $39 \pm 3$ & $3.1 \cdot 10^{-5}$ \\
17.08 & $1.5 \pm 0.1$ & $9.5 \pm 0.7$ & $19.8 \pm 0.9$ & $6.4 \cdot 10^{-3}$ \\
17.68 & $0.6 \pm 0.1$ & $10 \pm 1$ & $19 \pm 2$ & $2.4 \cdot 10^{-3}$ \\
& & $2.8 \pm 0.3$ & $10.0 \pm 0.1$ & $2.6 \cdot 10^{-3}$ \\
15.85 & $12.2 \pm 0.9$ & $\mathrm{CuPc}\left(4-\mathrm{NO}_{2}\right)_{4}$ & & $1.8 \cdot 10^{-5}$ \\
16.67 & $1.7 \pm 0.1$ & $36 \pm 2$ & $58 \pm 2$ & $10.4 \cdot 10^{-8}$ \\
17.08 & $1.4 \pm 0.2$ & $24 \pm 2$ & $45 \pm 3$ & $3.4 \cdot 10^{-7}$ \\
17.68 & $0.54 \pm 0.04$ & $20.3 \pm 1.5$ & $29 \pm 3$ & $2.0 \cdot 10^{-9}$ \\
& & $10.3 \pm 0.9$ & $23 \pm 2$ & $4.2 \cdot 10^{-6}$ \\
15.85 & $3.7 \pm 0.4$ & $\mathrm{CuPc}(4-\mathrm{Br})_{4}\left(5-\mathrm{NO}_{2}\right)_{4}$ & & $6.4 \cdot 10^{-6}$ \\
16.67 & $4.0 \pm 0.2$ & $10.2 \pm 0.7$ & $33.2 \pm 0.2$ & $2.3 \cdot 10^{-7}$ \\
17.08 & $1.13 \pm 0.07$ & $16.1 \pm 0.4$ & $24 \pm 2$ & $8.9 \cdot 10^{-9}$ \\
17.68 & $0.67 \pm 0.03$ & $14.0 \pm 0.9$ & $19.8 \pm 0.6$ & $16.4 \pm 0.9$ \\
\hline
\end{tabular}

In concentrated $\mathrm{H}_{2} \mathrm{SO}_{4}$ there are several proton-donor particles in the equilibrium concentrations: non-ionized $\mathrm{H}_{2} \mathrm{SO}_{4}$ molecules, $\mathrm{H}_{3} \mathrm{O}^{+}$cations and also $\mathrm{HSO}_{4}{ }^{-} \mathrm{H}_{3} \mathrm{O}^{+}$ion pairs and $\mathrm{H}_{2} \mathrm{O}$ molecules in 
trifling amounts [8]. The latter may be left out on account of the considered solvent concentrations ( $\mathrm{C}_{\mathrm{H}_{2} \mathrm{SO}_{4}}>15.8 \mathrm{~mole} / \mathrm{L}$ ). Non-ionized $\mathrm{H}_{2} \mathrm{SO}_{4}$ molecules and $\mathrm{H}_{3} \mathrm{O}^{+}$cations may be active particles when copper(II)phthalocyanines dissociate because the process demands protonation of donor $\mathrm{N}$-atoms. It is known that the ratio of the activity coefficients of the acid and base forms remains constant in this range of $\mathrm{H}_{2} \mathrm{SO}_{4}$ concentrations. This allows us to use for our calculation the equilibrium concentrations instead of activities. The equilibrium concentrations of particles in $\mathrm{H}_{2} \mathrm{SO}_{4}$ at $298 \mathrm{~K}$, calculated from the Hammet equation [9], were taken from [8]. The temperature dependencies of $\mathrm{H}_{0}$ and $\mathrm{pK}_{\mathrm{H}_{2} \mathrm{SO}_{4}^{-}}$were taken from [10,11]. As $\mathrm{C}_{\mathrm{H}_{2} \mathrm{SO}_{4}}^{0}$ increases the concentration of non-ionized $\mathrm{H}_{2} \mathrm{SO}_{4}$ molecules reduces and concentration of $\mathrm{H}_{3} \mathrm{O}^{+}$increases. Thus $k_{o b s}$ constants, which reduce in value as $\mathrm{C}_{\mathrm{H}_{2} \mathrm{SO}_{4}}^{0}$ increases, correlate with the equilibrium concentration of $\mathrm{H}_{3} \mathrm{O}^{+}$(Figure 2). The dependence is linear (Equation 4) for all investigated compounds at the temperatures shown in Tables 2,3 (the correlation coefficient is equal to $0.96 \div 0.99$ ). The reaction order dependence on the $\mathrm{H}_{3} \mathrm{O}^{+}$concentration $(n)$ which is equal numerically to tangent of the angle of inclination of the lines in Figure 2 is found to be close to 2 for three investigated nitro derivatives $\mathrm{CuPc}\left(3-\mathrm{NO}_{2}\right)_{4}, \mathrm{CuPc}\left(4-\mathrm{NO}_{2}\right)_{4}$ and $\mathrm{CuPc}(4-\mathrm{Br})_{4}\left(5-\mathrm{NO}_{2}\right)_{4}$.

$$
k_{o b s}=k_{d i s} \cdot C_{H_{3} O^{+}}^{n}
$$

For $\mathrm{CuPc}(4-\mathrm{Br})_{4}\left(5-\mathrm{NO}_{2}\right)_{4}$ maximums of the $\mathrm{k}_{\mathrm{obs}} v s . \mathrm{C}_{\mathrm{H}_{2}}^{0} \mathrm{SO}_{4}$ dependencies at temperatures $410 \mathrm{~K}$ and $379 \mathrm{~K}$ are observed at the same $\mathrm{C}_{\mathrm{H}_{2} \mathrm{SO}_{4}}$ values as maximums of the $\mathrm{C}_{\mathrm{H}_{3} \mathrm{O}^{+}} v \mathrm{~s}$. $\mathrm{C}_{\mathrm{H}_{2} \mathrm{SO}_{4}}^{0}$ dependence [8,12]. The extreme character of $k_{o b s}$ vs. $\mathrm{C}_{\mathrm{H}_{2} \mathrm{SO}_{4}}^{0}$ dependence for $\mathrm{CuPc}(4-\mathrm{Br})_{4}\left(5-\mathrm{NO}_{2}\right)_{4}$ can be accounted for by participation of $\mathrm{H}_{3} \mathrm{O}^{+}$cations as active particles in the dissociation processes. For $\mathrm{CuPc}\left(3-\mathrm{NO}_{2}\right)_{4}, \mathrm{CuPc}\left(4-\mathrm{NO}_{2}\right)_{4}$ the rate constants decrease with increasing solution acidity is considerably larger (Table 2). Perhaps because of this the $k_{o b s} v s . C_{H_{2}}^{0} \mathrm{SO}_{4}$ dependence becomes insensitive to the mentioned extreme of $\mathrm{C}_{\mathrm{H}_{3} \mathrm{O}^{+}} v s . \mathrm{C}_{\mathrm{H}_{2} \mathrm{SO}_{4}}^{0}$ dependence.

In equation (4) $k_{d i s}$ is the real rate constant of Reaction 1. Its values and corresponding values of the activation parameters are shown in Table 4. Data for non-substituted CuPc are taken from [1].

The dissociation reaction of carboxy derivatives of copper(II)phthalocyanine is more complex because the dependence of the order of Reaction 1 on $\mathrm{C}_{\mathrm{H}_{3} \mathrm{O}^{+}}$changes for different carboxy derivatives and temperature conditions (Table 5). It makes it impossible to determine the activation parametres of the dissociation of $\mathrm{CuPc}(\mathrm{COOH})_{\mathrm{m}}$. 
Table 3. Kinetic parameters of dissociation reactions of carboxy derivatives of copper(II)phthalocyanine in sulphuric acid.

\begin{tabular}{|c|c|c|c|}
\hline Compound & $\mathrm{T}, \mathrm{K}$ & $\mathrm{C}_{\mathrm{H}_{2} \mathrm{SO}_{4}}$, mole/L & $k_{o b s .} \cdot 10^{4}, \mathrm{~s}^{-1}$ \\
\hline $\mathrm{CuPc}(3-\mathrm{COOH})_{4}$ & 379 & $\begin{array}{l}16.85 \\
17.00 \\
17.72 \\
\end{array}$ & $\begin{array}{c}1.08 \pm 0.08 \\
0.08 \pm 0.01 \\
0.062 \pm 0.001\end{array}$ \\
\hline $\mathrm{CuPc}(4-\mathrm{COOH})_{4}$ & $\begin{array}{l}379 \\
410 \\
423\end{array}$ & $\begin{array}{l}16.03 \\
16.85 \\
17.00 \\
17.72 \\
15.85 \\
16.60 \\
17.00 \\
17.68 \\
15.85 \\
16.60 \\
17.00 \\
17.68\end{array}$ & $\begin{array}{c}5.1 \pm 0.1 \\
1.7 \pm 0.2 \\
0.58 \pm 0.05 \\
0.47 \pm 0.04 \\
33 \pm 3 \\
15 \pm 1 \\
8.8 \pm 0.5 \\
4.7 \pm 0.3 \\
57 \pm 8 \\
40 \pm 4 \\
17 \pm 2 \\
12 \pm 1\end{array}$ \\
\hline $\mathrm{CuPc}(3,5-\mathrm{COOH})_{8}$ & $\begin{array}{l}379 \\
410 \\
423\end{array}$ & $\begin{array}{l}16.03 \\
16.85 \\
17.00 \\
17.72 \\
15.85 \\
16.60 \\
17.00 \\
17.68 \\
15.85 \\
16.60 \\
17.00 \\
17.68 \\
\end{array}$ & $\begin{array}{c}0.40 \pm 0.04 \\
0.23 \pm 0.02 \\
0.22 \pm 0.04 \\
0.18 \pm 0.04 \\
2.5 \pm 0.2 \\
1.1 \pm 0.1 \\
0.59 \pm 0.02 \\
0.27 \pm 0.02 \\
5.4 \pm 0.3 \\
2.1 \pm 0.3 \\
1.4 \pm 0.1 \\
0.65 \pm 0.03\end{array}$ \\
\hline $\mathrm{CuPc}(4,5-\mathrm{COOH})_{8}$ & $\begin{array}{l}379 \\
410 \\
423\end{array}$ & $\begin{array}{l}16.03 \\
16.85 \\
17.00 \\
17.72 \\
15.85 \\
16.60 \\
17.00 \\
17.68 \\
15.85 \\
16.60 \\
17.68\end{array}$ & $\begin{array}{c}2.20 \pm 0.07 \\
0.56 \pm 0.09 \\
0.25 \pm 0.04 \\
0.15 \pm 0.02 \\
10 \pm 1 \\
5.1 \pm 0.4 \\
2.0 \pm 0.1 \\
0.95 \pm 0.03 \\
24 \pm 1 \\
12 \pm 2 \\
2.6 \pm 0.2 \\
\end{array}$ \\
\hline
\end{tabular}


Taking into account the ability of carboxy groups to act as weak organic acids for protonation in concentrated $\mathrm{H}_{2} \mathrm{SO}_{4}$ we suppose that reaction (1) of carboxy substituted copper(II)phthalocyanine is forestalled with the pre-equilibrium depicted in Equation 5 and its stoichiometric mechanism depends on nature of the compound and temperature.

$$
\mathrm{CuPc}(\mathrm{COOH})_{\mathrm{m}}+\mathrm{xH}_{\text {Solv }}^{+} \stackrel{K}{=}>\mathrm{CuPc}(\mathrm{COOH})_{\mathrm{m}} \mathrm{H}_{\mathrm{x}}^{+}
$$

Therefore the complete kinetic equations 6 and 7 correspond to the dissociation reactions of nitro and carboxy substituted copper(II)phthalocyanines, respectively.

$$
\begin{aligned}
& { }^{-d C_{C u P c}(R)_{m} H^{+}} / d \tau=k_{d i s} \cdot C_{C u P c}(R)_{m} H^{+} \cdot C_{H_{3} O^{+}}^{2} \\
& -d C_{C u P c}(R)_{m} H^{+} / d \tau=k \\
& { }_{d i s} \cdot K \cdot C_{H_{3} O^{+}}^{2+x} \cdot C_{C u P c}(R)_{m} H^{+}
\end{aligned}
$$

\begin{tabular}{|c|c|c|c|c|c|c|}
\hline \multirow[t]{2}{*}{ Compound } & \multicolumn{4}{|c|}{$k_{d i s} \cdot 10^{6}, \mathrm{~s}^{-1}$} & \multirow{2}{*}{$\begin{array}{c}\mathrm{E}, \\
\mathrm{kJ} / \text { mole }\end{array}$} & \multirow{2}{*}{$\begin{array}{c}\Delta \mathrm{S}_{\neq} \\
\mathrm{J} /(\text { mole } \mathrm{K})\end{array}$} \\
\hline & $379 \mathrm{~K}$ & $410 \mathrm{~K}$ & $423 \mathrm{~K}$ & $298 K$ & & \\
\hline $\mathrm{CuPc}\left(3-\mathrm{NO}_{2}\right)_{4}$ & 0.18 & $1.58^{\mathrm{a})}$ & 15.8 & $2.5 \cdot 10^{-5}$ & 158 & 28 \\
\hline $\mathrm{CuPc}\left(4-\mathrm{NO}_{2}\right)_{4}$ & 0.80 & 26.9 & $160^{\mathrm{b})}$ & $1.3 \cdot 10^{-6}$ & 172 & 79 \\
\hline $\mathrm{CuPc}(4-\mathrm{Br})_{4}\left(5-\mathrm{NO}_{2}\right)_{4}$ & 0.62 & 8.1 & 300 & $1.05 \cdot 10^{-5}$ & 231 & 224 \\
\hline $\mathrm{CuPc}[1]^{\mathrm{c})}$ & 0.242 & 280 & 1694 & $1.4 \cdot 10^{-6}$ & 149 & 30 \\
\hline
\end{tabular}

Table 4. The rate constants $k_{d i s}$, the activation energies and entropies of dissociation of nitro derivatives of copper(II)phthalocyanines in sulphuric acid.

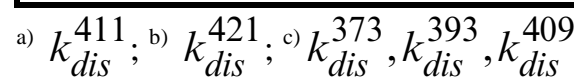

Thus only nitro derivatives and non-substituted $\mathrm{CuPc}$ may be placed in a series of kinetic stability to the hydroxonium cation action as far as they are compounds of the same type and dissociate according to one and the same mechanism. Value of $k_{d i s}{ }^{298 K}$ increases in series shown in Equation 8:

$$
\mathrm{CuPc}\left(4-\mathrm{NO}_{2}\right)_{4} \leq \mathrm{CuPc}<\mathrm{CuPc}(4-\mathrm{Br})_{4}\left(5-\mathrm{NO}_{2}\right)_{4}<\mathrm{CuPc}\left(3-\mathrm{NO}_{2}\right)_{4}
$$

Values of the activation energy of reaction (1) change in the same order (Table 4). This can mean that in the series 8 the compounds are placed in accordance with destabilization of the $\mathrm{Cu}-\mathrm{N}$ bonds from beginning to end of the series. Taking account of the mixed $\sigma \pi$ character of the $\mathrm{Cu}-\mathrm{N}$ bonds with the $\pi$ dative bond direction from $\mathrm{Cu}$ to $\mathrm{N}$ [1] the order of the compounds in the series (8) can be explained from the point of view of the electron influence of $\mathrm{NO}_{2}$ and $\mathrm{Br}$ substituents on the electron density of 
the bonds. Obviously the negative inductive effect of the substituents has little influence on state of the $\mathrm{M}-\mathrm{N}$ bonds because of remote location of the substituents from the coordination center (Formula I). In reality, not all the complexes are less stable than $\mathrm{CuPc}$.

Table 5. The rate constants $k_{d i s}$ and the reaction orders $n$ of the dissociation of carboxy derivatives of copper(II)phthalocyanines in sulphuric acid.

\begin{tabular}{|cccc|}
\hline Compound & T.K & $-\lg k_{\text {dis }}$ & $n$ \\
\hline $\mathrm{CuPc}(3-\mathrm{COOH})_{4}$ & 379 & 10.2 & 6.4 \\
$\mathrm{CuPc}(4-\mathrm{COOH})_{4}$ & 379 & 6.9 & 3.2 \\
& 410 & 5.3 & 2.5 \\
& 423 & 3.9 & 1.2 \\
$\mathrm{CuPc}(3,5-\mathrm{COOH})_{8}$ & 379 & 6.7 & 2.2 \\
& 410 & 7.0 & 3.0 \\
$\mathrm{CuPc}(4,5-\mathrm{COOH})_{8}$ & 423 & 6.4 & 2.8 \\
& 379 & 7.6 & 3.6 \\
& 410 & 6.8 & 3.6 \\
& 423 & 6.5 & 3.6 \\
\hline
\end{tabular}

The nitro groups in $\mathrm{CuPc}\left(4-\mathrm{NO}_{2}\right)_{4}$ are para-substituents with regard to the $\mathrm{C}$ atom in position 1 and meta-substituents with regard to the $\mathrm{C}$ atom in position 2. Inasmuch as the $\mathrm{H}_{3} \mathrm{O}^{+}$attack on the reaction centre $\mathrm{CuN}_{4}$ is a complex nucleophilic-electrophilic process with two types of interaction $(\mathrm{O} \rightarrow \mathrm{Cu}$ and $\mathrm{H} \leftarrow \mathrm{N}$ ), the $\pi$-withdrawing effect of the nitro groups can appear from para- and meta-substitution as well. Then $4-\mathrm{NO}_{2}$ groups can stabilize the copper(II)phthalocyanine due to strengthening of the dative $\pi$ -bonds $\mathrm{Cu} \rightarrow \mathrm{N}$. This stabilization effect takes place in reality (Series 8). The result of analogous analysis for 3-NO $\mathrm{NO}_{2}$ substituted copper(II)phthalocyanine in which $\mathrm{NO}_{2}$ groups are simultaneously ortho- and para-substituents with regard to $\mathrm{C}$ atoms in positions 2 and 1 is the same. However, 3- $\mathrm{NO}_{2}$ groups are less conjugated with the benzene ring because of close positions of mezo $\mathrm{C}$ atoms of the macrocycle. Observed destabilization of $\mathrm{CuPc}$ when $3-\mathrm{NO}_{2}$ is the substitutent (Series 8) shows that the negative Ieffect of the substituents takes place all the same. In the 4- $\mathrm{NO}_{2}$ derivative the substituents are farther from the reaction center and the induction effect is imperceptible.

$\mathrm{CuPc}(4-\mathrm{Br})_{4}\left(5-\mathrm{NO}_{2}\right)_{4}$ is less stable compared with $\mathrm{CuPc}$ due to mutual steric hindrances of adjacent $\mathrm{Br}-$ and $\mathrm{NO}_{2}$ - groups to conjugation with the macrocycle and their negative induction effect.

Regularities of the change of the activation parameters of the dissociation reaction of copper(II)phthalocyanine with functional substitution (Table 4) are in good correspondence with the considered mechanism of the electronic influence. Larger values of $E$ and $\Delta S_{\neq}$correspond to the more stable complex $\mathrm{CuPc}\left(4-\mathrm{NO}_{2}\right)_{4}$ as compared with $\mathrm{CuPc}$. An increase in strength of the donor-acceptor bonds $\mathrm{Cu}-\mathrm{N}$ because of $\pi$-electron withdrawing effect of $\mathrm{NO}_{2}$ groups leads to a sharp increase of the 
activation energy value, which is not compensated by changes of effectiveness of the nucleophilic interaction $\mathrm{O} \rightarrow \mathrm{Cu}$. $(\Delta \mathrm{S} \neq$ increases $)$. For less stable $\mathrm{CuPc}\left(3-\mathrm{NO}_{2}\right)_{4}$ on the contrary, a decrease of $\mathrm{E}$ and $\Delta \mathrm{S} \neq$ values is observed. For $\mathrm{CuPc}(4-\mathrm{Br})_{4}\left(5-\mathrm{NO}_{2}\right)_{4}$ the activation parameters are close to those for the non-substituted complex.

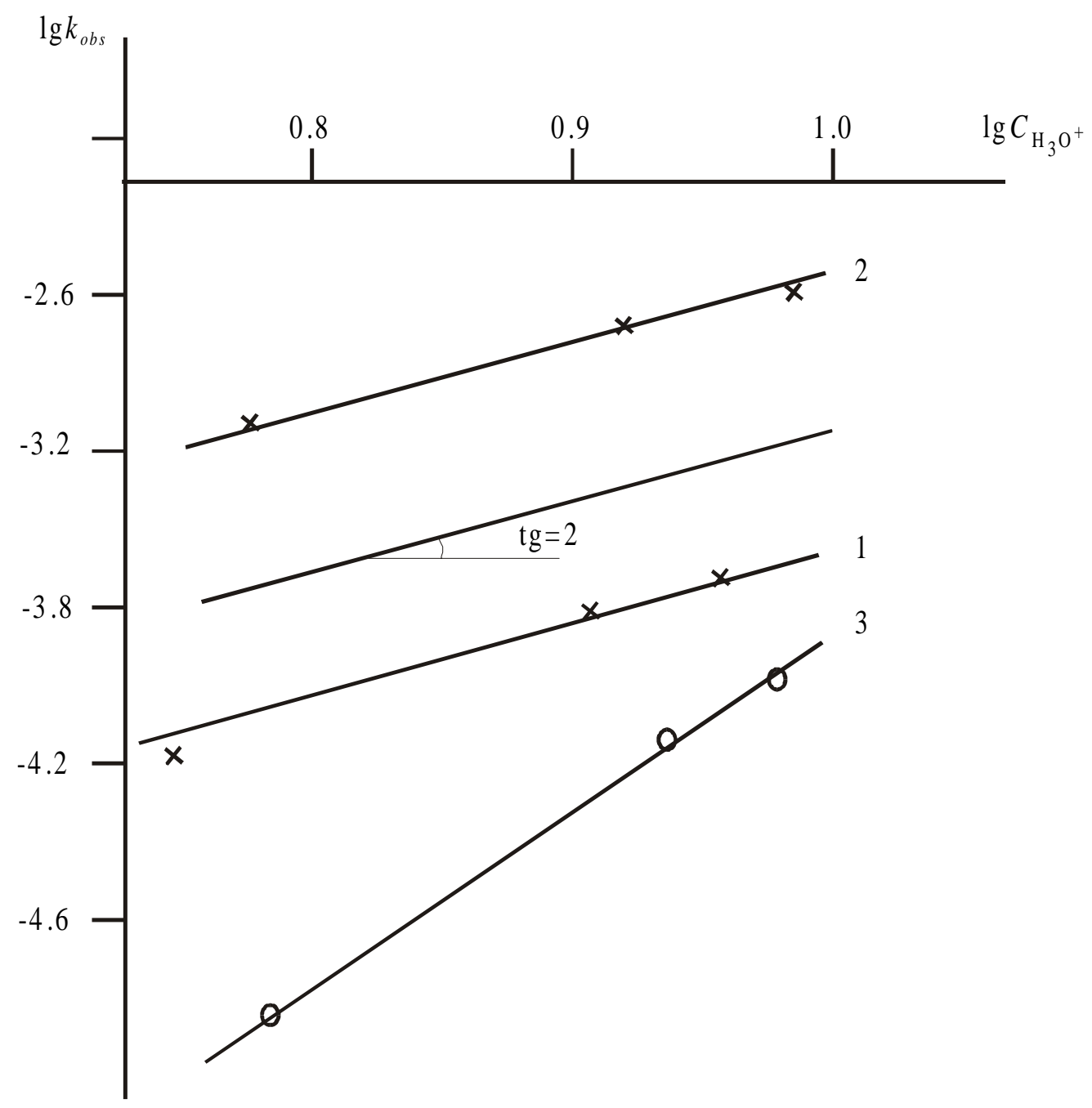

Figure 2. $\lg k_{o b s}-\lg C_{H_{3} O^{+}}$dependence for $\mathrm{CuPc}\left(3-\mathrm{NO}_{2}\right)_{4}(1), \mathrm{CuPc}\left(4-\mathrm{NO}_{2}\right)_{4}(2)$ and $\mathrm{CuPc}(3,5-$ $\mathrm{COOH})_{8}(3) . \mathrm{T}, \mathrm{K}: 1-379,2,3-410$.

An analogous mechanism for the electronic influence of substituents on reactivity in dissociation by dint of influence of the electronic state of the metal - nitrogen bonds was observed also for the earlier investigated metalloporphyrins substituted in $\beta$-positions of the macrocycle [13].

The CuOEP studied in the present work is significantly less stable compared with coppertetraphenylporphyrin (CuTPP) (for CuOEP $k_{o b s}^{298}$ is equal $1.310^{-5}, \mathrm{~s}^{-1}$ in mixed solvent $0.15 \mathrm{M}$ $\mathrm{H}_{2} \mathrm{SO}_{4}$ in $\mathrm{CH}_{3} \mathrm{COOH}$; for CuTPP $k_{o b s}^{298}$ is equal $1.510^{-6}, \mathrm{~s}^{-1}$ in $0.5 \mathrm{M} \mathrm{H}_{2} \mathrm{SO}_{4}$ in $\mathrm{CH}_{3} \mathrm{COOH}$ ) due to an 
electron donating action of alkyl groups onto the reverse dative $\mathrm{M}-\mathrm{N} \pi$-bond.

For numerous functional derivatives of metallotetraphenylporphyrins substituted in the benzene rings, the mechanism of the electron influence of the substituents is essentially different: substitution leads basically to changes of state of the n-electron pairs of the $N$ atoms of the metalloporphyrins $[14,15]$. Our data show that eight alkyl groups introduced into phenyl rings of CuTPP instead of $\beta$-positions of the macrocycle decreases the complex stability only within the limits of an order of magnitude ( $k_{o b s}^{298}$ are equal $6.9610^{-4}, \mathrm{~s}^{-1}$ for $\operatorname{CuTP}\left(3,4-\mathrm{di}-\mathrm{CH}_{3}\right)_{4} \mathrm{P}$ and $1.08 \cdot 10^{-4}, \mathrm{~s}^{-1}$ for CuTPP in $1 \mathrm{M} \mathrm{H}_{2} \mathrm{SO}_{4}$ in $\left.\mathrm{C}_{3} \mathrm{H}_{7} \mathrm{COOH}\right)$.

\section{Experimental}

Functional derivatives of copper(II)phthalocyanin were synthesized by the template method from corresponding derivatives of $o$-phthalodinitrile and copper acetate and then purified by standard methods [7]. CuOEP was obtained by the coordination reaction of copper acetate with octaethylporphyrin in dimethylformamide and purified by column chromatography $\left(\mathrm{Al}_{2} \mathrm{O}_{3}, \mathrm{CHCl}_{3}\right)$. UVvis spectra were recorded on a Specord M400 spectrophotometer.

\section{References and Notes}

1. Berezin, B. D. Coordination Compounds of Porphyrins and Phthalocyanines; Wiley: New York Toronto, 1981; p 286.

2. Boston, D. R.; Bailar, J. C. Inorg. Chem. 1972, 11, 1578-1583.

3. Weber, H.; Busch, D. Inorg. Chem. 1965, 4, 469-471.

4. Gaspard, S.; Verdquer, M.; Vioig, K. C. R. Acad. Sc. Series C, Paris 1972, 275, 573-579.

5. Elektronnije spektri phthalocyanina i rodstvennih soedineniy; Lukianetz, E. A., Ed.; ONIITEChIM: Chercassi, 1989; p 94.

6. Phthalocyanines: Properties and Application; Leznoff, C. C., Ed.; VCH Publishers, Inc.: 1996; Vol. IV, p 515.

7. Lever, A. B. P. Advances Inorg. and Radiochem. 1965, 7, 28-114.

8. Majorov, V. D.; Librovich, N. B. Zh. Fiz. Khim. 1973, 47, 2298-2301.

9. Hammet, L. P.; Deyrup, A. J. A. Series of Simple Basic Indicators. 1. The Acidity Function of mixtures of Sulfuric and Perchloric Acids with Water. J. Amer. Chem. Soc. 1932, 54, 2721-2739.

10. Vinnik, M. I. Dokladi AN SSSR 1956, 107-108.

11. Gelbshtein, A. I.; Zheglova, G. G.; Temkin, M. Sh. Zh. Neorgan. Khim. 1956, 1, 506.

12. Liler, M. Reaction Mechanisms in Sulphuric Acid; Academic Press: London - New York, 1971; p 280.

13. Klyueva, M. E.; Lomova, T. N.; Berezin, B. D. Russian Journal of General Chemistry 1991, 61, 1131-1136. 
14. Lomova, T. N.; Shormanova, L. P.; Semeykin, A. S.; Voronina, E. V.; Berezin, B. D. Zh. Obshch. Khim. 1988, 58, 661-665.

15. Lomova, T. N.; Mozhzhukhina, E. G.; Shormanova, L. P.; Berezin, B. D. Russian Journal of General Chemistry 1989, 59, 2077-2084.

Samples Availability: Available from the authors.

(C) 2000 by MDPI (http://www.mdpi.org). Reproduction is permitted for noncommercial purposes. 